\title{
Identifying an Optimal Lending Rate for the Sustainable Development of Microfinance Institutions in Vietnam
}

\author{
Lê Văn Luyện \\ Banking Academy \\ luyenlvhvnh@yahoo.com
}

\section{ARTICLE INFO}

Received:

April 15, 2013

Received in revised form April 24, 2013

Accepted:

June 15, 2013

Keywords:

microfinance institutions optimal lending rate national microfinance network (M7)

Affectionate Fund under

Vietnam Women's Union

\section{ABSTRACT}

The paper discusses methods of identifying the optimal lending rate for microfinance institutions and focuses on the application of internationally-acclaimed CGAP (Consultative Group to Assist the Poor) model to identifying the lending rate for microfinance institutions. The paper also aims at providing a scientific overview that may help readers understand microfinance institutions, their operations in Vietnam and ways of applying CGAP lending rate identification model to local conditions and offer one more option to policy makers and other institutions. The research employs quantitative methods and data presented by M7 group at the workshop "Identification of Sustainable Interest Rate for Microfinance Institutions" held in Hà Nội in March 2012. 


\section{INTRODUCTION}

In recent decades, the microfinance practice has been known as the operation of small-sized financial institutions. The practice aims to financially support the poor in the rural and urban areas. In Vietnam, in recent years, especially since Decree 28/2005/NĐ$\mathrm{CP}$ was promulgated, official and semiofficial microfinance institutions have mushroomed and operated quite efficiently, contributing substantially to the poverty alleviation and hunger eradication in the rural and mountainous areas. However, there have appeared shortcomings through their operation, especially the determination of an appropriate lending rate, which must be tackled so as to develop Vietnam's microfinance institution sustainably in Vietnam.

In this paper, the author would like to look into a matter of concern to microfinance institutions: the legal system related to SBV policy on interest rate. For instance, the ceiling of $13 \%$ per annum on VND lending rate as prescribed in the Circular 33/2012/TT-NHNN dated Dec. 21, 2012 has become a controversial issue. A majority of microfinance institutions believes that such a rate is not sufficient to offset costs and thus it cannot motivate semiofficial microfinance institutions to operate officially. Accordingly, it is very difficult for the government to control their operation and ensure the healthy operation of the entire finance market. Therefore, formulation and promulgation of related regulations at the service of the healthy operation of microfinance institutions in time to come become urgent.

\section{MICROFINANCE INSTITUTIONS AND THE OPTIMAL LENDING RATE}

\section{a. Theoretical Background Concerning Microfinance Institutions:}

According to CGAP (Consultative Group to Assist the Poor) under the World Bank (WB), microfinance refers to the provision of primary financial services to the poor, such as savings, loans, pensions, transfer, insurance, etc. In the meantime, the Asian Development Bank (ADB) defines microfinance as the provision of financial services such as deposits, loans, payments, transfer and insurance to the poor and low-incomed households as well as small-sized enterprises.

In developing countries, especially destitute ones, in past time, microfinance is an effective tool to alleviate poverty and eradicate hunger. Microfinance services include not only credit services for the poor to develop their business but also risk management services. Accordingly, it enables the poor to make the efficient use of their available resources such as land, workforce, and the like to generate incomes and improve their 
life. Microfinance also helps the poor diversify their sources of income from handicrafts, trading and small business in addition to that from farming; and thereby enabling them to alleviate life and business risks. Additionally, according to Nguyễn Kim Anh et al. (2012), it is also a channel to distribute financial services to the society and fill gaps in the finance market. In short, it is apparent that microfinance is both a financial intermediary service and a social activity; and criteria to evaluate and manage the practical operation of microfinance institutions must be formulated on the basis of both financial and social activities.

\section{b. Lending Rate of Microfinance Institutions and the Optimal Lending Rate:}

The interest rates of microfinance institutions include the deposit interst rate and the lending rate. These rates, in basic terms, are identical to those of other banking institutions; yet it is also necessary to consinder other distinctive features of microfinance such as customer, scale of deposits and loans, territory, and other costs incurred by the microfinance institution. The optimal lending rate adopted by a microfinance institution is a lending rate at which it can offset costs, gain an appropriate accumulation of profit, and simultaneously ensure the solvency of the poor borrowers.

\section{RESEARCH METHODOLOGY AND DATASET}

The reasearch employs the quantitative method based on the CGAP's model for determining the lending rate of microfinance institutions. Accordingly, the optimal lending rate (per annum) is expressed by the following formula:

$$
R=\frac{A E+L L+C F+K-I I}{1-L L}
$$

where:

$\mathrm{R}$ : Lending rate

AE: Administrative costs

LL: Loan losses

CF: Cost of funds

K: Desired capitalization rate

II: Investment income

The CGAP's model has included input costs to be offset such as capital costs (input interest rate) including inflation rate, administrative costs; and other losses to be offset 
to maintain the business such as loan losses (sunk costs due to risks), the desired capitalization rate, and accumulative appropriate income.

The dataset used for calculation is collated from recent publications of Microfin (a microfinance institution in the South America), Mexico, Uganda, Kenya, Uzbekistan, India, Sri Lanka and Senegan, whose microfinance networks are quite developed. Regarding Vietnam, the author employs the official numerical data of TYM Fund (an affectionate fund under the Union of Vietnamese Women) and M7 group.

According to CGAP, the lending rate for the poor is often exorbitant in comparsion with that of commercial banks due to the high risk and the tiny scale of loans for the poor. The cost per VND lent, the lending dossier appraisal cost, the administrative cost, and the deposit mobilization cost of microfinance institutions are always higher than those of commercial banks. Compared to commercial banks, microfinance institutions do not often possess a convenient business place, and their staff must even contact each household in person to mobilize tiny savings and conduct a transaction. In addition to lending, microfinance institutions also supply other non-finanical services, thus the cost rises accordingly. Related costs include costs of group formation and those for financial and social knowledge propagation, which commercial banks need not cover and hardly have any cost of the kinds. Apparently, the difference between microfinance institutions and normal banks leads to a tremendous difference in their interest rate.

Given the theoretical background and the experience from microfinance institutions in the world, CGAP extends some suggestions for microfinance institutions to identify an optimal or sustainable interest rate which can enable them to offset costs of operation, overheads and inflation for one thing; and for another, facilitate the solvency of the poor. For example, with the financial data from Microfin in 2012, the following values are inserted into the aforementioned formula: $\mathrm{AE}=0.25 ; \mathrm{LL}=0.02, \mathrm{CF}=0.21 ; \mathrm{K}=0.16$ and II =0.015 (cited in Lê Lân, 2013), the interest rate will be:

$$
R=\frac{0.25+0.02+0.21+0.16-0.015}{1-0.02}=0.638
$$

Thus, the lending rate of Microfin should be 0.638 (63.8\%); in other words, Microfin can extend loans to its customers at the interest rate of $64 \%$ per annum or $5.3 \%$ per month. Yet it is noticed that microfinance institutions in South America often adopt an exorbitant lending rate, which depends on the macroecnomic policies (e.g. high VAT, no subsidy, etc.). According to CGAP (2008), the interest rate of Mexico is above 65\% 
and is followed by Uganda and Kenya (above 50\%), and the highest interest rate falls to Uzbekistan (over 80\%); in the meantime, the interst rates of India, Sri Lanka and Senegan are very low, ranging between 17\% and 20\% (Figure 1). Aslo, CGAP (2008) determines an annual average interst rate of $35 \%$ for microfinance institutions, which has not much fluctuated up to now. However, this average rate will be adjusted over time in accordance with model's variables.

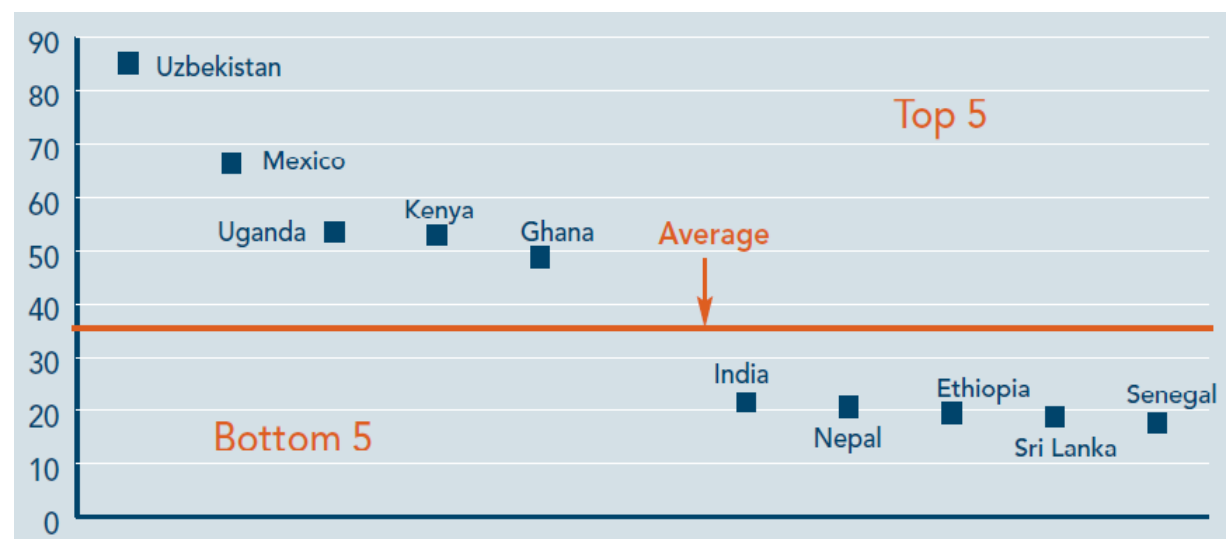

Figure 1: The Interest Rate of Some Microfinance Institutions in the World in 2008

Source: CGAP (2008)

\section{MICROFINANCE INSTITUTIONS IN VIETNAM AND IDENTIFICATION OF THE LENDING RATE}

\section{a. Vietnam's Microfinance Institutions and Financial Services:}

Microfinance has made its appearance in Vietnam for a long time in the form of small loans extended to the rural poor by the rich. The poor use such loans to pay for living necessities and preparations for new crops, or overcome consequences of some disasters, etc. In the 1980s, some semiofficial microfinance institutions appeared via socioeconomic collaboration programs between international organizations such as SIDA (Swedish), ActionAid, etc. and Vietnam. In 2005, Decree 28/2005/NĐ-CP set up the first legal framework for the operation of microfinance institutions; and then Decree $165 / 2007 / \mathrm{NĐ}-\mathrm{CP}$ amending to and modifying the previous Decree 28 required microfinance institutions to observe the goal of sustainable development. At present, official microfinance institutions of Vietnam are comprised of TYM Fund under the Union of Vietnamese Women, M7 Group, Capital Aid Fund for Employment of the Poor (CEP), and some other semiofficial ones in Tiền Giang, Thanh Hóa, etc. 
Regarding present-day microfinance services in Vietnam, the 2010 Law on Banking Institutions prescribes that microfinance is a type of credit supply at the service of lowincome individuals and households and micro-enterprises. Microfinance institutions in Vietnam often provides services related to savings, lending, payment, transfer, insurance, consultancy, and other supports for the poor and low-income individuals.

Besides TYM Fund and CEP Fund which are quite large-sized institutions, there are also semiofficial microfinance institutions with a very small seed capital, such as capital aid funds for women's economic development (CWED), as shown in the following data:

- For the seed capital: Until late 2012, the seed capital of microfinance institutions is very humble. For example, Thanh Hóa CWED just holds about VND20 million while it is just nearly VND10 million for the case of Bình Phước CWED and some others.

- For deposits (including compulsory and voluntary deposits from members of the institution): Until late 2012, the compulsory deposit for formation of the women development fund has ranged between some millions of dongs (e.g. above VND9 million in Uông Bí CWED) to tens of millions of dongs (e.g. Hải Phòng CWED with over VND80 million). In addition, the amount of voluntary deposits is very low; the largest fund is merely around VND70 million (e.g. Hải Phòng) while those with VND10 million to VND40 million make up the majority.

- For lending: The average loan from Vientam's microfinance institutions is millions of dongs, or even smaller than VND1 million. By the end of 2012, apart from TYM Fund and CEP Fund, the outstanding loan ratio of microfinance institutions just approximates tens of millions of dongs such as Hải Phòng CWED with around VND60 million, Hà Tĩnh CWED with VND58 million, and Bình Minh CWED with smaller than VND10 million. In the meantime, such outstanding loans are scattered over a larger number of customers such as Hải Phòng CWED with 9,000 customers, Hà Tĩnh CWED with 26,000 customers and Bình Minh CWED with around 5,000 customers. Accordingly, each customer, on average, borrows around VND2 million.

- For payment and insurance: Some microfinance institutions have planned to implement services of payment and transfer related to other banks and the state treasury. Regarding insurance services, related policies are still amended to help and allow microfinance institutions to act as authorized agencies of insurers.

\section{b. Analyzing the Lending Rate Applied to Financial Services of Vietnam's Microfinance Institutions:}


In the current context of Vietnam, there are many shortcomings in the mechanism of management and policies concerning microfinance institutions; and the true nature, costs, and interest rate of all types of credit services in general and of microfinance institutions in particular have not been precisely assessed. The governmental advisory panel in charge of the operation of microfinance institutions should differentiate the credit type for the poor (such as microfinance) and the normal one. The poor, in addition to their need for loan capital, also need supports for production techniques, financial management knowledge, and effective use of loan capital. When a microfinance institution provides a financial service, it should simultaneously extend social supports. Because microfinance services are very different from commercial bank's financial services, it is necessary to formulate an appropriate legal system for microfinance services.

SBV, by Circular 33/2012/TT-NHNN promulgated on Dec. 21, 2012 (or Circular 33 for short), imposes an interest rate cap on VND short-term loans of banking institutions and branches of foreign banks in order to meet the need of some fields and industries of the national economy. As prescribed in the Item 1, Article 1 of Circular 33, the maximum interst rate of VND short-term loans shall be $12 \%$ per annum for commercial banks and $13 \%$ for people's credit funds and microfinance institutions. The Circular 33 was validated on Dec. 24, 2012 and shall take place of Circular 14/2012/TT-NHNN and Circular 20/2012/TT-NHNN which was to amend some points of Circular 14. With the annual interest rate cap of $13 \%$ as set by Circular 33, microfinance institutions have really faced difficulties because it is much lower than their really-adopted interst rate. Additionally, with regard to Decision 652/2001/QĐ-NHNN dated May 17, 2001 by SBV concerning the interest rate calculation, microfinance institutions shall calculate the interest rate in accordance with an amortization schedule. This method, in fact, is suitable for commercial bank, yet seems infeasible for microfinance organizations and their poor customers. Due to the fact that the outstanding debt of these customers is very small, just around a half of a million dongs or millions of dongs (the largest ones merely approximate tens of millions of dongs), the periodically payable interest rate and principal is not substantial. Thus, with this method, microfinance institutions may face difficulties calculating the periodically payable interest rate and principal, inspecting, and collecting loans.

At present, only TYM Fund and M7 Group are affected by Circular 33. Yet, in time to come, many other semiofficial institutions are recognized to be official ones, such as 
Thanh Hóa CWED, Tiền Giang CWED (or Mekong Organization of Microfinance MOM), and CEP Fund of HCMC; and they will also have to observe Circular 33 as well. The interst rate policy can hinder the official operation of semiofficial microfinance institutions in Vietnam.

In the next section, the CGAP's model will be employed to examine why there is a big difference in the interest rate of microfinance institutions and how the real interest rate is calculated.

\section{c. Testing the Lending Rate in Accordance with the CGAP's Model:}

Lending rates of microfinance institutions such as TYM Fund and M7 Group, if the CGAP's formula is taken into account, are all higher than $30 \%$. Specifically, given the 2012 numerical data of M7 Group (citied in Nguyễn Đức Bình, 2012), that is, AE = $0.142 ; \mathrm{LL}=0.01 ; \mathrm{CF}=0.057 ; \mathrm{K}=0.1 ; \mathrm{II}=0$, the interest rate $(\mathrm{R})$ will be 0.0311 (i.e. $31.1 \%$ p.a. and $2.61 \%$ per month). It is at the annual interest rate higher than $30 \%$ that TYM Fund and M7 Group will be able to cover costs, loan losses and inflation cost in order to develop sustainably. Some semiofficial microfinance institutions have adopted an annual interest rate of over $24 \%$ (or $2 \%$ per month), which is lower than that of official ones because they cannot audit sufficiently operating costs, especially costs for related activities; and their microfinance services are often combined with other activities of the women's union, which are to some extent subsidized. Once they are officially acknowledged to be official microfinance institutions, their activities must be detached from those of other government organizations and audited thoroughly. Accrodingly, their operating cost will rise and must be reflected in the operating cost statement. In brief, semiofficial microfinance institutions should step by step establish an appropriate interest rate to develop their business sustainably.

\section{d. Impacts of Interest Rate Ceiling Policies on the Operation of Microfinance Institutions in Vietnam:}

In order to comply with the SBV Cirular 33, microfinance institutions should calculate thoroughly their operating and managing costs. Given the 2012 numerical data of M7 Group concering the operating costs, its pre-tax income and profit decreases by VND14,457 million and VND12,073 million respectively. However, if M7 Group observes the method set forth in Decision 652/2001/QĐ-NHNN dated May 17, 2001 by the SBV Governor, its profit is expected to reach VND14,457 million; and this figure will be much higher if the CGAP's method is employed. Besides, also according to 
Circular 33, in order to keep the profit larger than zero, it must cut $69 \%$ of operating costs and the entire non-financial costs; and thus around 15,300 poor customers cannot access loans. In brief, in order to facilitate the healthy operation of microfinance institutions like M7 Group and TYM Fund as well as to enable poor customers to access loans, the government's macroeconomic policies, particularly regulations concerning the interest rate of microfinance institutions must be adjusted appropriately.

\section{RECOMMENDATIONS}

Through the aforementioned theoretical background and analyses, the author would like to extend several suggestions as follows:

First of all, the interest rate ceiling for microfinance institutions in Vietnam should be calculated on the basis of the optimal interest rate model of CGAP in order for microfinance institutions to be able to offset costs and retain approrpriate earnings and for poor customers to remain solvent. By so doing could the microfinance institutions develop sustainably. If the current interest rate ceiling is employed, it is advantageous to borrowers since they can enjoy a low interest rate; yet it is insufficient for lenders to offset costs. Once the income cannot offet expenses, the working capital, which mainly derives from compulsory and voluntary deposits of institution members, will soon run out; and the institution cannot maintain their operation. The employment of the optimal interest rate model of CGAP will promote the development of official microfinance institutions, improve the rural financial market, and contribute substantially to the hunger eradication and poverty alleviation.

Secondly, it is advised to let microfinance institutions apply the agreed-upon interest rate as allowed by Decree 41/2010/NĐ-CP dated April 12, 2010, that is, the interest rate based on the market supply and demand and somehow modified by the optimal interest rate of the CGAP's model. Microfinance institutions, given their scale and costs, can identify an appropriate lending rate. The employment of agreed-upon interest rate policy will stimulate microfinance institutions to step by step improve their management, save costs, and enhance credibility to attract capital sources at the low cost. Simultaneously, microfinance institutions should depend on their capital sources and customers' needs to formulate an appropriate lending rate, which will facilitate the circulation of capital and show interest in the way the customers use loans.

Thirdly, microfinance institutions should be allowed to adopt an equal interest rate during the amortization schedule for the sake of both borrowers and lenders. For 
example, if a customer borrows VND10 million within a year with the interest rate of $12 \%$ per annum, he or she must pay the total interest of VND1.2 million. The lender can adopt the amortization schedule for 24 instalments (i.e. two instalments per month) (Table 1):

\section{Table 1: Sample Calculation of the Equal Interest Rate of Microfinance Institutions (VND1,000)}

\begin{tabular}{cccc}
\hline Instalment & Principal payable & Interest payable & Total \\
\hline 1 & 409 & 50 & 459 \\
2 & 417 & 50 & 467 \\
3 & 417 & 50 & 467 \\
$\cdot$ & $\cdot$ & $\cdot$ & $\cdot$ \\
$\cdot$ & $\cdot$ & $\cdot$ & $\cdot$ \\
$\cdot$ & $\cdot$ & $\cdot$ & $\cdot$ \\
24 & 417 & 50 & 467 \\
\hline Total & $\mathbf{1 0 , 0 0 0}$ & $\mathbf{1 , 2 0 0}$ & $\mathbf{1 1 , 2 0 0 , 0 0 0}$ \\
\hline
\end{tabular}

With each instalment of VND467,000, the borrower must pay VND934,000 per month. For the first instalment alone, the principal payable of VND409,000 is the residue after the total loan is divided by 24 . The borrower just has to remember that the total amount payable in each instalment is VND467,000 or VND934,000 per month. Accordingly, while the accounting practice of microfinance institutions is not professional, and the borrower's financial knowledge is not sufficient either, this method is supposed to be not only easy for borrowers but also convenient for the accounting and management of the lender without affecting its business performance.

Finally, legal stipulations regarding the interest rate and accounting in microfinance institutions should be in accordance with distinctive features of their territories and type of credit supply. At present, TYM Fund has its branches mainly established in plains such Hà Nội and Vĩnh Phúc; while M7 Group operates in mountaineous areas such as Điện Biên and Sơn La. Therefore, credit products and calculation of costs and interest rate of M7 Group will be different from that of TYM Fund. For example, debt collection of M7 Group is merely done once a month while it is done weekly in TYM Fund.Yet in 
general, the fact that microfinance institutions let their customers repay the loan in instalments is a good policy to maintain their solvency and simultaneously stimulate them to find a good way to improve their life. In the past, the positive role of microfinance institutions in the rural finance market has contributed a lot to the hunger eradication and poverty alleviation; thus Vietnam should formulate incentive policies to facilitate the development of microfinance institutions

\section{References}

CGAP (2008), "Brief Variations in Microcredit Interest Rates" available at http://www.cgap.org/sites/default/files/CGAP-Brief-Variations-in-Microcredit-Interest-RatesJul-2008.pdf và http://www.cgap.org/publications/variations-microcredit-interest-rates.

Lê Lân (2013), "Vấn đề lãi suất và tài chính vi mô", presented in the seminar "Xác định lãi suất bền vững cho các tổ chức TCVM (Identifying a sustainable interest rate for microfinance institutions)" held in Hà Nội in March 2013.

Nguyễn Đức Bình (2013), "Xác định lãi suất của M7-MFI”, presented in the seminar "Xác định lãi suất bền vững cho các tổ chức TCVM (Identifying a sustainable interest rate for microfinance institutions)" held in Hà Nội in March 2013.

Nguyễn Kim Anh et al. (2012), Phát triển tài chính vi mô ở khu vực nông nghiệp, nông thôn, a research project of scientific field level, Code: KNH 2009-06. 